\title{
Prepozycje. Metafizyka „bliskości”
}

\section{Grzegorz Pertek}

W artykule Śledzenie (śladów) sensu. Tekst i lektura w hermeneutyce ponowoczesnej Patryk Szaj, forsując radykalnohermeneutyczny sposób rozumienia tekstu i jego lektury, zaproponował, by tę ostatnią uprawiać jako: „[...] kroczenie po śladach tekstu i podążanie w ślad za ich znaczeniorodną grą..." ${ }^{1}$. Co znaczy owo drobne i - wydawałoby się - pozbawione znaczeniorodności „po”, które znalazło miejsce w powyższym - kluczowym, jak sądzę, dla ontologii tekstu jako „śladu” - stwierdzeniu? Czy wskazuje ono na jakąś (jaką?) relację pomiędzy lekturą a tekstem? Tekstem a śladem? Czy „ślady tekstu” znaczą dokładnie to samo, co „ślady po tekście”? Jeśli nie, to z czym wiązałoby się wsunięcie tego drobiazgu pomiędzy „ślady” i „tekst”? A co z kolei oznaczałoby jego przesunięcie na inną pozycję, właściwą dla formuły „po śladach tekstu”?

Hermeneutyka radykalna ma czerpać jednocześnie z dwóch tradycji, z jednej strony zachowywać (oczywiście tylko do pewnego stopnia) ciągłość w stosunku do własnej „przeszłości”, do klasycznych hermeneutyk, na przykład hermeneutyki Hansa-Georga Gadamera czy Paula Ricoeura, z drugiej natomiast potraktować serio lekcję dekonstrukcji Jacques’a Derridy, eksponując jej hermeneutyczny aspekt, uzupełniając - z jej inspiracji - ograniczający hermeneutykę „semiotyczny deficyt” (ŚŚ, s. 85, 86). Już takie zaprojektowanie pola metodologicznego nie jest niewinne, albowiem sugeruje, że hermeneutyka i dekonstrukcja (a wcześniej pewnie także strukturalizm) pozostawały dotychczas w relacji konfliktowej, którą hermeneutyka radykalna (czy ponowoczesna) będzie starała się (bądź już to robi) przezwyciężyć, wypracowując własną, oryginalną strategię lekturową, polegającą na konsekwentnym, choć specyficznie rozumianym trzymaniu się „blisko tekstu” (ŚŚ, s. 80). Chciałbym w niniejszym komentarzu do artykułu Szaja przyjrzeć się pokrótce, w jaki sposób jedna z centralnych kategorii tego tekstu, kategoria „bliskości”, organizuje proponowany przez Szaja układ wewnątrz pola metodologicznego.

\footnotetext{
${ }^{1}$ P. Szaj, Śledzenie (śladów) sensu. Tekst i lektura w hermeneutyce ponowoczesnej, „Forum Poetyki” 2017 (wiosna/
} lato), s. 88-89. Podkreślenia kursywą - G.P. Dalej w tekście głównym jako ŚŚ z podaniem numeru strony. 
„Bliskość” hermeneutyczna (transcendencja)

Kluczowy zarzut Jacques'a Derridy pod adresem hermeneutyki dotyczy uprawiania przez nią „lektury transcendentnej”, czyli takiej, która odsyła „[...] zawsze na zewnątrz samego tekstu, w stronę (fundującego go, uprzedniego względem niego) sensu. Hermeneutyczne «trzymanie się blisko tekstu» okazuje się zatem pozorne, gdyż tak naprawdę chodzi w nim o to, co poza samym tekstem" (ŚŚ, s. 82, wyr. kursywą - za źródłem). Relację pomiędzy tekstem i (jego) sensem można rozumieć, opierając się zresztą na tych samych cząstkowych sformułowaniach (np. sens poprzedza tekst; sens jest poza tekstem; sens jest na zewnątrz tekstu; sens funduje tekst), zarówno w kategoriach czasowo-przestrzennego przesunięcia, jak i zależności o charakterze strukturalno-genetycznym. „Zewnętrze” nie musi jednak wiązać się z potocznym myśleniem o przestrzeni jako rodzaju odstępu, przestrzeni ustanowionej „pomiędzy dwoma”, w tym wypadku pomiędzy tekstem i sensem. Trudno nawet wyobrazić sobie fizyczność takiej przestrzeni. Ani „zewnętrze”, ani „poza” o niczym jeszcze w tym momencie nie przesądzają, wszak jeden element wydaje się w tym ujęciu krytyki nader interesujący. Chodzi o powiązanie kwestii „zewnętrza” z problemem „bliskości” (lekturą „z bliska”). Predykat „bliskości” jest nie tylko uwikłany w wymiar czasowy i przestrzenny (przyczyna/skutek; wnętrze/zewnętrze), to akurat jego - powiedzmy - „naturalna” (słownikowa) przypadłość ${ }^{3}$. Został on również jawnie wplątany - nie wiedząc zresztą, dlaczego - w odmienną opozycję pozoru i prawdziwości ${ }^{4}$. Biegun „prawdziwości” nie pojawia się explicite w zacytowanym fragmencie. Kto wie, czy to nieobojętne skądinąd przemilczenie, którego niewątpliwie konsekwencją jest przestawienie ostrza krytyki, nie wymierzonej przecież - czego moglibyśmy się spodziewać (właśnie po dekonstrukcji) - w ideę „bliskości” w ogóle, lecz w „prawdziwość” tej konkretnej formy „bliskości” lektury „zewnętrznej”, jaką uprawia hermeneutyka, kto wie zatem, czy to przemilczenie nie ciąży na całym tekście Szaja (być może prawda „bliskości” nie odnalazła jeszcze własnego znaczącego). O „prawdziwej” bądź „pozornej” formie „bliskości” rozstrzygać ma bowiem pozycja (nie jest to jednak zbyt fortunne określenie) sensu względem tekstu. Zgodnie z przyjętą logiką, jeśli „bycie poza” (lub: „bycie na zewnątrz”) demaskuje (odsłania) pozór „bliskości”, to jej faktyczność (prawdziwość) może zagwarantować jedynie „bycie w”5 (zob. ŚŚ, s. 83). Opozycja wnętrze/ zewnętrze (przynajmniej w jednym miejscu utożsamiona z opozycją signifiant - signifié [ŚŚ, s. 83]), właśnie za sprawą „bliskości”, która może się jawić jako „pozorna” lub „prawdziwa” (a która sama także umieszczona została nie w neutralnym, lecz skonfliktowanym polu krytyki

\footnotetext{
2 Zob. J. Derrida, Pozycje, przeł. A. Dziadek, Katowice 2007, s. 91. Dalej w tekście głównym jako P z podaniem numeru strony.

3 „Bliskim” może być: 1) ten/to, kto/co znajduje się w niewielkiej odległości; 2) to, co ma nastąpić w niedalekiej przyszłości; 3) coś, co jest niedawno przeszłe; 4) coś, co jest dokładne, szczegółowe, sprecyzowane; 5) ktoś/coś spokrewniony/e z kimś/czymś bezpośrednio; też: wyrażający taki stosunek; 6) ktoś/coś mający/e pewne cechy zbieżne z kimś/czymś; 7) ktoś ściśle złączony uczuciami, poglądami; też: będący wyrazem takiego złączenia. Relacja „bliskości”, jak widzimy, może być relacją o charakterze wyłącznie podmiotowym (7), podmiotowym i/lub przedmiotowym $(1,5,6)$ oraz tylko przedmiotowym $(2,3,4)$. Zob. Słownik języka polskiego PWN https://sjp.pwn. pl/slowniki/bliski.html [dostęp: 10.03.2018].

${ }^{4}$ Odrębne, poboczne niejako pytanie powinno dotyczyć również tego, czy „bliskość” należałoby wiązać z określoną ontologią tekstu, czy raczej ontologią lektury? Na ile kwestie te są ze sobą nierozerwalnie związane? ${ }^{5}$ Czy coś, co „jest (już) w” czymś nadal (jeszcze) jest temu czemuś „bliskie”? Czy - chociażby - przepisując tekst słowo w słowo, litera po literze (jak w słynnym opowiadaniu Borgesa) jesteśmy wciąż jeszcze „bliscy” tekstowi, który przepisujemy? Gdzie jesteśmy, cytując go (nawet w całości), gdzie zaś, tylko parafrazując? Czy cytowanie (i parafrazowanie również) jest po stronie „w”, czy może po stronie „poza”? A może ani „w”, ani „poza” jednocześnie? Czy oprócz „w” i „poza” możliwe jest coś jeszcze? Jakaś trzecia pozycja?
} 
lektury hermeneutycznej), nie jest jakimś „pokojowym współistnieniem jakiegoś vis-à-vis”, lecz - przeciwnie - „konfliktową i uzależniającą strukturą” hierarchii nie pozbawionej przemocy, gdzie aksjologicznie „jeden z terminów kieruje drugim”, jeden zajmuje wyższą pozycję niż drugi (zob. P, s. 41). „Bliskość”, przynajmniej w jednym z zawartych w niej wątków znaczeniowych, nieskrycie uprzywilejowuje „wnętrze”. Dlatego niewiele może mieć ona wspólnego na przykład z rozsunięciem, o którym Derrida pisze, że „[...] jest pojęciem, które zawiera w sobie, chociaż nie tylko, znaczenie siły produktywnej, pozytywnej, generującej. Podobnie jak rozplenienie, jak różnia, zawiera motyw genetyczny" (P, s. 91, wyr. kursywą - za źródłem). Rozsunięcie: „[...] oznacza też niemożliwość zredukowania łańcucha do jednego z jego ogniw lub uprzywilejowania jednego lub drugiego” (P, s. 92). „Bliskości” - przynajmniej chwilami - zdecydowanie bliżej do przestrzenności rozumianej w sposób prosty, tj. jako odległości dzielącej coś od czegoś.

Pozorna „bliskość” tradycyjnej hermeneutyki, czyli „bliskość” zorientowana na sens, „bliskość" - rzekomo i na odwrót - uprzywilejowująca sens i jego „zewnętrzność” względem tekstu, nie może być zatem tą zapowiadaną na początku, specyficzną „bliskością” orientacji radykalnohermeneutycznej ${ }^{6}$. Tekst jest tylko „wytworem pośrednim”, „epifenomenem” (ŚŚ, s. 81), tekst daje się sprowadzić jedynie do „postaci wtórnej” wobec poprzedzającej go prawdy lub sensu, konstytuowanych przez „żywioł logosu i w tym żywiole” (ŚŚ, s. 82). Czy fakt, że jej („bliskości”) wektor skierowany został w stronę „zewnętrznego sensu”, uprawnia nas do tego, abyśmy taką lekturową orientację uznali za relację oddalającą? Czy „zewnętrze” implikuje sobą jakieś oddalenie? Fragment, od którego wyszliśmy, poprzedza następujące zdanie: „[...] całe przedsięwzięcie hermeneutyczne okazuje się chybione ze względu na [...] «milczące założenie», że tekst posiada sens” (ŚŚ, s. 82, wyr. G.P.). Zwróćmy uwagę, że już w słowie „chybione" zaczyna prześwitywać to spore (jednak) ryzyko związane z wprowadzeniem podejrzanej kategorii „bliskości”, zwłaszcza że mogłaby ona w jego świetle oznaczać po prostu trafienie w punkt (do czego zresztą zmierzać będzie - jak niebawem zobaczymy - lektura ujmowana za pomocą metafory „dotkliwości”, a co nieuchronnie zakłada już jakiś telos ${ }^{7}$ ). Jeśli przekonanie o istnieniu sensu, jego istnieniu w ogóle - podkreślmy - jest nieuzasadnione, to na jakiej podstawie można określić pozycję tegoż sensu względem tekstu? Jego „zewnętrzność”? Czy konstatacja mówiąca o „pozornej” jedynie „bliskości” nie opiera się, jednak, na „milczącym założeniu", chwilowej być może wierze, że sens jednak istnieje, tyle że - i na tym polega cały kłopot - osadzony został przez hermeneutykę w niewłaściwym miejscu, to jest „na zewnątrz” tekstu? Czy stwierdzenie „autentyczności pozoru”, do którego musi prędzej czy później dojść, bo przecież pozór musi się jakoś uwiarygodnić (znamienna forma antytezy: „[...] gdyż tak naprawdę chodzi w nim o to..." (ŚŚ, s. 82) - uwalnia go z kleszczy cudzysłowu), nie potrzebuje, z jednej strony, tej wiary w prawdziwość „zewnętrza” (w faktyczne wykroczenie sensu), by jednocześnie z drugiej - co możemy sobie dość łatwo wyobrazić - poprzez negację (a jest to jedyny sposób), mógł się zarysować kontur prawdziwej „bliskości”, która pełnię osiąga

\footnotetext{
${ }^{6}$ „[...] radykalnohermeneutyczna relacja z tekstem bynajmniej nie jest dowolna, przeciwnie - spełnić zadanie hermeneutyczne z całym radykalizmem, to właśnie trzymać się «blisko tekstu». Rzecz w tym, że zarówno sam «tekst», jak i «bliskość» są tu pojmowane specyficznie” (ŚŚ, s. 80, wyr. G.P.).

7 Może nawet więcej, lektura „dotkliwa” (ale też „dotkliwość” tekstu interpretowanego, np. wiersza), jest lekturą celną, trafną, albo zgodną. Chcąc jednak mówić o tekście poza kategoriami celu lub zastosowania, musielibyśmy całkowicie zaprzestać mówienia o znaczeniu tekstu i sposobach jego rozumienia, w zamian zaś zacząć mówić, w duchu Manowskim, o jakimś rodzaju „widzenia materialnego” (Zob. W.B. Michaels, Kształt znaczqcego. Od roku 1967 do końca historii, przeł. J. Burzyński, Kraków 2011, s. 13-14).
} 
wtedy i tylko wtedy, gdy jako pewne oddalenie (i tylko tak) dąży do zera? Czy oznacza to, że stająca się „bliskość”, możliwa do pomyślenia właśnie jako redukowana nieustannie odległość, rośnie dokładnie wtedy, gdy maleje? Czy „bliskość” jest w pełni dopiero wtedy, kiedy jej zupełnie nie ma? Czy zasadne jest mówić w jej kontekście o „wzrostach” i „spadkach”? „[T] ekst i czytelnik - cytuje Szaj w pewnym miejscu Paula Ricoeura - kolejno się do siebie zbliżają i od siebie oddalają” (ŚŚ, s. 80). Czy „bliskość” jest w związku z tym wymierna, czy można ją zmierzyć i jakimi środkami należałoby to robić? A może - przeciwnie - „bliskość”, to kwestia zaledwie dwóch niezmiennych pozycji, zera („w”) i jedynki („poza”)?

Jeśli mimo wszystko należy odrzucić hermeneutyczny „sens”, semiotyczne „znaczone”, transcendentalne signifié (ŚŚ, s. 83), generalnie - porzucić myśl o tych właśnie i wszystkich innych, także niedosłownych (nieliteralnych) formach „zewnętrza” tekstu, znamionujących pewną stałą, choć nieokreśloną odległość, czy wówczas faktyczność „bliskości” nie staje się dla czytającego nieuchronna? Czy nieobecność przekraczającego, wymykającego się za każdym razem w lekturze sensu nie sprawia, że „bliskość” staje się przeklęta, skazując tym samym czytelnika na powtarzanie w nieskończoność eksperymentu Borgesa?

\section{„Bliskość” dekonstrukcyjna (immanencja)}

Na czym polega „bliskość” lektury dekonstrukcyjnej, skoro ta jest „sztuką mikrolektury par excellence"? (ŚŚ, s. 83). Czy oznacza to zarazem, że lektura dekonstrukcyjna (jako mikrolektura właśnie) jest skazana na „bliskość”? W jakim sensie „bliskość” dekonstrukcyjną można postrzegać jako „prawdziwszą” od „bliskości” tradycyjnej hermeneutyki?

O statusie „bliskości” lektury hermeneutycznej przesądza pozycja sensu całościującego (gwarantującego pełnię rozumienia), który jako taki zawsze sytuuje się (i przestrzennie, i czasowo oraz pod każdym innym względem) „na zewnątrz” tekstu (dzieła), więc jest przez tekst nieosiągalny, gdyż nie odpowiada mu żadne signifiant, a każdym z tych, które - ewentualnie - tekst podsuwa, nie może się zadowolić. Skoro pragnieniem hermeneutyki jest znaleźć się możliwie „blisko” sensu (lub go w jakiś sposób osiągnąć), a ten sytuuje ona zawsze „poza” tekstem, który jest dla niej z kolei wyłącznie „środkiem do...”, to „bliskość”, idąc w ślad za nim, to jest opuszczając tekst, oddalając się od niego, nie może być jednocześnie „bliskością” wobec tekstu. Wektor interpretacji odbywającej się w duchu „bliskości” wobec tekstu skierowany być jednak powinien w przeciwną stronę, „do wewnątrz”. Lektura hermeneutyczna staje przed alternatywą: zdradza literę, która stanowi, wedle tej logiki, granicę tekstu, ignoruje formę, pomija signifiant - czyni to wszystko na rzecz „transcendentalnego signifié”. Istota zawierałaby się w tym, co tkwi niejako pomiędzy dwoma orientującymi biegunami, tekstem i sensem (a także pod pewnym względem: signifiant i signifié). Problem polega na tym, że „bliskość” lektury hermeneutycznej, jeśli ta jest $-\mathrm{w}$ istocie - lekturą transcendentną, $\mathrm{z}$ trudem daje się pomyśleć jako ruch oddalania od tekstu (będącego jednocześnie ruchem zbliżania się do sensu), a nawet wykraczania "poza” tekst, ponieważ nigdy w historii interpretacji nie zdarzył się moment, w którym sens opuściłby tekst. Otóż sens nigdy nie opuścił tekstu, albowiem od zawsze był on „na zewnątrz”, a skoro tak, to nie da się wyjąć z tekstu czegoś, co nigdy nie było „w środku”, chyba że założymy, iż każda zorientowana na sens lektura hermeneutyczna zawiera w sobie 
„pierwotny” moment „immanentny”, który byłby „momentem semiotycznym”, „momentem tekstualnym" (jakimś punktem znakowego zaczepienia), który nie byłby zarazem niczym innym, jak tylko uchwytnym wytworem nieuchwytnej prawdy sensu (w pewnym miejscu pojawia się w formie pytania podobne przypuszczenie: „[...] jakiś «element dekonstrukcyjny» mieści się już w samym środku doświadczenia hermeneutycznego?" [ŚŚ, s. 84]).

„Bliskość" dekonstrukcyjna nie musi mierzyć się z tym problemem. Nie dotyczy bowiem sensu transcendującego tekst, bo taki sens, jej zdaniem, w ogóle nie istnieje. Można by rzec natomiast - tautologicznie - że tekst, wedle dekonstrukcji, znaczy właśnie to, co znaczy. I nic poza tym. W związku z tym dekonstrukcja, stając poniekąd w obliczu tej samej alternatywy, wybiera odwrotnie: „wnętrze” tekstu zamiast jego „zewnętrza”, signifiant pojedynczego słowa występującego „w" konkretnym środowisku tekstowym zamiast signifié wykraczające "poza” ów tekst: „[n]a dochowaniu wierności [...] grze znaczących polega lektura, którą autor O gramatologii nazywał «nietranscendentną», nieporzucającą zainteresowania dla znaczącego, formy, języka, materii, z jakiej ustrukturyzowany został tekst" (ŚŚ, s. 83).

„U Joyce’a potrafiłem jedynie wydzielić dwa słowa (He war albo yes, yes); u Celana jedno słowo obce (Shibboleth); u Blanchota jedno słowo i dwa homonimy (pas). Nigdy jednak nie twierdziłbym, że «przeczytałem» lub zaproponowałem ogólną lekturę tych dzieł". Listę tę, jak wiadomo, uzupełnić by można wieloma przykładami: „hymen” u Mallarmégo, „suplement” u Rousseau, „farmakon” u Platona, „parergon” u Kanta, „skandal zakazu kazirodztwa” u Levi-Straussa... To skupienie Derridy na pojedynczych wyimkach z czytanych (ale nie prze-czytanych) przez niego tekstów stanowi [...] ważny element jego strategii, polegającej na podkreślaniu roli pisma i jego znaczeniorodności, która rozgrywa się nie na zewnątrz tekstu, na poziomie znaczonego (np. znaczonego sensu), ale właśnie w jego wnętrzu, na poziomie znaczących ${ }^{8}$.

Dla lektury dekonstrukcyjnej „«sens» jest efektem samego tekstu” (ŚŚ, s. 84, wyr. G.P.), dlatego „nie można wyciagnać (w sensie: wyjąć na zewnątrz) sensu z tekstu, gdyż on zawsze znajduje się $w$ tekście, w archi-tekście" (ŚŚ, s. 84, wyr. kursywą - za źródłem). Wytworem tekstu jest sens, ale nade wszystko jego wytworem jest także transcendencja sensu. Dlatego Szaj przywoła w określonym momencie pewien impas: „Lektura transcendentna jest niemożliwa [...] Ale lektura transcendentna jest także konieczna” (ŚŚ, s. 84). Sensu nie sposób „wyjąć na zewnątrz”, ponieważ korzeń transcendencji sensu znajduje się „, środku” tekstu. Dekonstrukcja - wedle zainicjowanej przez Szaja opozycji - uwewnętrznia transcendencję i czyni ją sobie podległą ${ }^{9}$, czego jednym z efektów może być hermeneutyczny moment wewnątrz dekonstrukcji. O tym, że rozumienie lektury dekonstrukcyjnej ześlizguje się tutaj wyraźnie w odwrotność lektury uprawianej przez tradycyjną hermeneutykę, świadczy także i to, że sens i tekst dosłownie zamieniają się miejscami ${ }^{10}$. Teraz sens (jako efekt właśnie) stanowi skutek, a tekst przyczynę (odwrócenie

\footnotetext{
${ }^{8}$ ŚŚ, s. 83, wyr. G.P. Cyt. wewn.: Ta dziwna instytucja zwana literaturq. Z Jacques'em Derrida rozmawia Derek Attridge, przeł. M.P. Markowski, „Literatura na Świecie” 1998, nr 11-12, s. 210.

${ }^{9}$ Widać to zwłaszcza wtedy, gdy Szaj przyjmuje za Derridą, że „tekst sam z siebie nie potrafi uniknąć poddania się lekturze "transcendentnej»..." (ŚŚ, s. 83).

${ }^{10}$ Pojawiają się też inne figury odwrócenia, jak choćby „ «zwichnięte» koło dekonstrukcyjne” naprzeciw „koła hermeneutycznego albo Gadamerowska „nadwyżka sensu” usytuowana naprzeciw Derridiańskiego „nadmiaru signifiants" (ŚŚ, s. 85).
} 
genetycznej zależności ${ }^{11}$. Natomiast o tym, że dekonstrukcja pozostaje tutaj w dialektycznym uścisku z tradycyjną hermeneutyką, świadczy także to, że ujęcie „zewnętrza” tekstu (sens) jako wytworu samego tekstu jest (zgodnym $\mathrm{z}$ tradycją metafizyczną) ujęciem $\mathrm{z}$ ducha heglowskim $^{12}$. Zadaniu hermeneutyki, która dążyła do tego, by „skupić całość tekstu w prawdę sensu” (ŚŚ, s. 82), odpowiada po stronie dekonstrukcji - analogicznie - zadanie polegające na tym, by

${ }^{11}$ Czy w tak ostrym przeciwstawieniu, którego ośrodek stanowi hierarchiczna opozycja wnętrze/zewnętrze, Szaj nie idzie zbyt daleko? Nie idealizuje nieco sytuacji właśnie po to, by przygotować odpowiednio czytelne miejsce dla hermeneutyki ponowoczesnej, która w stosunku do tradycyjnej hermeneutyki, jak pisze, „stara się nadrobić ten semiotyczny deficyt” (wyr. G.P.), wychodząc z przekonania, że „tekst stanowi swoisty fenomen działający na przecięciu semiotyki i hermeneutyki”? (ŚŚ, s. 86). To przeciwstawienie sugeruje, że hermeneutyka ponowoczesna (dopiero ona) podjęła próbę „pogodzenia” dwóch odrębnych i a(nta)gonistycznych wobec siebie nurtów w humanistyce: „wewnętrznego” (fenomenologia, formalizm, strukturalizm, semiotyka i - dopisujemy - dekonstrukcja) oraz „zewnętrznego" (pozytywizm, marksizm i hermeneutyka). W innym miejscu (Czy można pogodzić dekonstrukcję z hermeneutyką? Dialog Derridy z Gadamerem, „Czas Kultury” 2014, nr 5, s. 68-74) Szaj napisze explicite o antagonistycznych stosunkach między dekonstrukcją a hermeneutyką. Nawet w postulacie potraktowania serio lekcji dekonstrukcji tkwi dotychczasowa jej negacja ze strony hermeneutyki. „Lekcja, jaką hermeneutyka ponowoczesna czerpie $z$ dekonstrukcji, polega więc przede wszystkim na baczniejszym zwracaniu uwagi na tekstualność (resp. znakowość) tekstu. Choć była ona dostrzegana już przez niektóre nurty hermeneutyki nowoczesnej (szczególnie przez Ricoeura), to jednak w koncepcjach Heideggera czy Gadamera [...] po prostu jej brakuje" (ŚŚ, s. 86). Obecność Heideggera jako tego, który winien być współodpowiedzialny za deficyt znakowości w hermeneutyce, może budzić co najmniej zdziwienie. Nigdy nie jest tak, że jakaś metodologia (lub jakaś teoria) jest albo „czysto” wewnętrzna (semiotycznie dodatnia), albo „czysto” zewnętrzna (semiotycznie ujemna). Interesujące, że na przykład Maria Janion hermeneutykę wywodzącą się od Heideggera nazwała niegdyś swoiście „strukturalizmem egzystencjalnym”, choć znacząco różniącym się od inspirowanego językoznawstwem „strukturalizmu fonologicznego", to jednak strukturalizmem, który - znów - w opozycji do modelu badań pozytywistycznych docenił formalno-estetyczny aspekt dzieła literackiego (zob. M. Janion, Humanistyka: poznanie i terapia, Warszawa 1982, s. 38, tu szczególnie studium zatytułowane Spór o genezę). Krytyczny gest dekonstrukcji wobec hermeneutyki w jakimś stopniu i pod względem formalnym powtarzałby (z przemieszczeniem oczywiście) gest rodzącego się na początku XX wieku formalizmu wobec orientacji pozytywistycznej. Formalistom także wydawało się wówczas, że zwracając uwagę na estetyczną stronę dzieła literackiego, zajmują się wreszcie, w przeciwieństwie do genetystów, tym, co stanowi istotę, czyli „literackością”, czyli „immanencją” tekstu. Dość szybko jednak uświadomiono sobie iluzyjność tego przeświadczenia.

Dekonstrukcja, gdyby uznać ją - oczywiście wbrew jej własnym intencjom - za metodę, nie jest ani metodą „zewnętrzną" (ignorującą znaczące), ani „wewnętrzną" (absolutyzującą znaczące). Nie tylko dlatego, iż ma za sobą długą (i poważną) lekcję strukturalizmu, ale że sam ów podział uznaje za wytwór własnego „odkrycia”, czyli różni: „[...] pojęcie różni nie jest ani po prostu strukturalistyczne, ani po prostu genetyczne, taka alternatywa sama jest «skutkiem» różni” (P, s. 13). Między innymi dlatego Anna Burzyńska napisze, że Derridzie „od samego początku” szło „o wyrwanie się z zamkniętego kręgu języka oraz hermetycznego «kokonu» tekstu, zredukowanego do wewnętrznej «gry znaczących»” (A. Burzyńska, Dekonstrukcja, polityka, performatyka, Kraków 2013, s. 519-520). Hermeneutyka ponowoczesna, decydując się na ruch „podwójnej negacji”, to jest negację negatywnego gestu dekonstrukcji, wpisuje się w dialektyczny spór z podobnym entuzjazmem, jaki towarzyszył chociażby Michałowi Głowińskiemu, gdy ten wraz z pojawieniem się „teorii komunikacji literackiej” ogłosił nastanie nowego paradygmatu w nauce o literaturze, wykraczającego poza podział metod na „zewnętrzne” i „wewnętrzne” (Zob. M. Głowiński, Od metod zewnętrznych $i$ wewnętrznych do komunikacji literackiej, [w:] Problemy teorii literatury. Seria 4. Prace z lat 1985-1994, wybór H. Markiewicz, Wrocław 1998, s. 456-469). Na temat zwrotu hermeneutyki w kierunku języka i mowy zob. G. Marzec, Poza głosem i fenomenem. W sprawie dekonstrukcji i hermeneutyki, [w:] Filozofia i etyka interpretacji, red. A.F. Kola, A. Szahaj, Kraków 2007, s. 121-130. Autor stawia między innymi tezę, co wydaje się szczególnie interesujące w świetle przeświadczenia o „deficycie semiotycznym” hermeneutyki, że jednym z zasadniczych zarzutów, jakie kieruje Derrida przeciwko hermeneutyce Heideggera, jest jego zafascynowanie wszechobecnością języka.

${ }^{12}$ „Hegel jako pierwszy dogłębnie pojął tę założeniową strukturę języka, dzięki której jest on zarazem poza sobą i w sobie, a to, co bezpośrednie (to, co niejęzykowe), nie okazuje się niczym innym, jak tylko założeniem przyjętym przez język. «Elementem doskonałym - pisze w Fenomenologii ducha - w którym wewnętrzność jest tak samo czymś zewnętrznym, jak zewnętrzność czymś wewnętrznym, jest i w tym wypadku również mowa». Jak jedynie suwerenna decyzja o stanie wyjątkowym otwiera przestrzeń, w której mogą być wytyczone granice między tym, co wewnętrzne, i tym, co zewnętrzne, a określone normy przypisane określonym terytoriom, tak język - tylko jako czysta możność oznaczania - wycofując się z wszelkich konkretnych instancji dyskursu, oddziela to, co językowe, od tego, co niejęzykowe i umożliwia powstanie znaczących obszarów dyskursu, w których pewnym terminom odpowiadają pewne denotaty. Język jest suwerenem, który pozostając w wiecznym stanie wyjątkowym, deklaruje, że nie ma niczego poza językiem i że zawsze jest poza sobą" (G. Agamben, Homo sacer. Suwerenna władza i nagie życie, przeł. M. Salwa, posł. P. Nowak, Warszawa 2008, s. 35, cyt. wewn: G.W.F. Hegel, Fenomenologia ducha, przeł. A. Landman, t. 2, Warszawa 1965, s. 332). 
zwinąć znaczące „całego" tekstu do postaci signifiant pojedynczego słowa (czasem nawet jednej, choćby niemej litery) ${ }^{13}$. Wśród wielu znaczeń „bliskości”, jakie odnotowuje każdy niemal słownik języka polskiego, znajduje się między innymi takie, które jej znaczenie oddaje właśnie przez to, co jest dokładne, szczegółowe, sprecyzowane. Słynną Różnię rozpoczyna Derrida zdaniem: „A zatem będę mówił o jednej literze” ${ }^{14}$. Czy zajmując się owym a w différance ${ }^{15}$, Derrida drąży język „do wewnątrz”, czy może jedynie rysuje jego „zewnętrzną” powierzchnię? Jak blisko siebie położone są signifiant i signifié? ${ }^{16}$

\section{Praxis „bliskości”}

Marian Stala jedną ze swoich książek poświęconych współczesnej poezji zatytułował Blisko wiersza. Formuła ta - jak sam przyznaje - to „najkrótszy wykład [...] krytycznoliterackiego programu”. Tłumaczy dalej, że: „[n]ajbliżej wiersza jesteśmy wtedy, gdy wmyślamy się we

\footnotetext{
${ }^{13}$ Przywoływany przez Szaja ustęp Derridy pojawia się - wbrew jego przekonaniu - w drugim wydaniu polskiego przekładu Pozycji („FA-art.”, Katowice 2007, przekł. A. Dziadka), choć brzmi on nieco inaczej: „zebranie całości tekstu w prawdę jego sensu" (s. 44). Pojawia się on w miejscu, w którym Derrida objaśnia różnicę między polisemią (wspomina o hermeneutycznej teorii polisemii Ricoeura), która, choć stanowi postęp w stosunku do „linearności pisma” lub „czytania monosemicznego”, to jednak nadal pozostaje w horyzoncie zagrożenia teleologią i eschatologią, a rozplenieniem [dissémination], które „by wytworzyć nie-skończoną liczbę efektów semantycznych, nie pozwala się sprowadzić ani do obecności prostego początku [...] ani do obecności eschatologicznej" (s. 44-45), głównie za sprawą swej mocy generatywnej. W jakiejś mierze więc polisemia jest jedynie efektem dyseminacji, jej obrazem. Zob. też: J. Derrida, Mallarmé, [w:] Sztuka interpretacji w ostatnim pótwieczu, wybór i oprac. H. Markiewicz, współudział T. Walas, Kraków 2011, t. 3, s. 220. Tam również pojawia się ta formuła „skupiska sensu” ograniczającego polisemię.

${ }^{14}$ J. Derrida, Różnia, przeł. J. Margański, [w:] tegoż, Marginesy filozofii, przeł. A. Dziadek, J. Margański, P. Pieniążek, Warszawa 2002, s. 29.

${ }^{15}$ Jaką funkcję pełni „a”? „Chodzi o to, aby wytworzyć nowe pojęcie pisma. Można je nazwać gramem lub różniq̨. [...] Żaden element, czy to w porządku dyskursu mówionego, czy dyskursu pisanego, nie może funkcjonować jako znak, nie odsyłając do innego elementu, który sam po prostu nie jest obecny. Ten szereg sprawia, że każdy «element» - fonem lub grafem - konstytuuje się począwszy od śladu, jaki pozostawiają w nim
} inne elementy łańcucha lub systemu. Ten szereg, ten splot jest tekstem, który wytwarza się wyłącznie przez przekształcenie innego tekstu. Nic - ani w elementach, ani w systemie - nie jest nigdzie i nigdy po prostu obecne lub nieobecne. Istnieją, na wskroś, wyłącznie różnice i ślady śladów. [...] Gram jako różnia jest [...] strukturą, o której nie można już myśleć w przez pryzmat opozycji obecność/nieobecność. Różnia jest systematyczną grą różnic, śladów różnic, rozsunięcia, poprzez które elementy odnoszą się jedne do innych. To rozsunięcie jest wytwarzaniem, zarazem aktywnym i pasywnym [a różni (différance) oznacza to niezdecydowanie w stosunku do aktywności i pasywności, coś, co nie pozwala jeszcze kierować i czego nie można rozplanowywać przez tę opozycję], odstępów, bez których terminy «pełne» nie mogłyby znaczyć ani funkcjonować. Jest to także stawanie się przestrzenią łańcucha mówionego - który nazwano czasowym i linearnym; stawanie się przestrzenią - jedynie ono samo umożliwia pismo i wszelką zgodność pomiędzy mową a pismem, wszelkie przejścia od jednego do drugiego" (P, s. 27-28, wyr. przez rozstrzelenie - G.P.). Owo „a”, widzimy, do którego zbiega się powyższy fragment wypowiedzi Derridy (a jest ono wtrącone w nawias), jako „ślad śladów” stanowi końce i początki poszczególnych elementów łańcucha systemu, system mikrorozcięć.

${ }^{16}$ Zewnętrzność „transcendentalnego signifié" (istnienie której zakłada tradycyjna hermeneutyka) byłaby prawdziwie (radykalnie i absolutnie) pozajęzykowa. Nie wynikałaby bowiem jedynie z różnicy między signifiant i signifié znaku: „[...] «transcendentalne signifié», które nie odsyłałoby samo z siebie, ze swej istoty do żadnego signifiant, wykraczałoby poza łańcuch signifiants i w pewnej chwili samo przestałoby funkcjonować jako signifiant” (P, s. 21). Czy oznacza to zarazem, że „wnętrze” (pewnie równie radykalne, równie prawdziwe) należy sytuować na poziomie znaczących? Czytamy dalej (u Derridy): „[...] od chwili, kiedy zaczyna się wątpić w możliwość takiego transcendentalnego signifié i dostrzega się, że wszelkie signifié znajduje się także w pozycji signifiant, rozróżnienie pomiędzy signifié i signifiant - znak - staje się problematyczne u samych korzeni” (P, s. 21). Ale przecież Derrida mówi także bardzo często o piśmie, które by „dosłownie nic-nieznaczyło”, o ryzyku wejścia do „gry różni”, związanej z tym, aby nic-nie-znaczyć (P, s. 17). Czy w takiej grze, „która sprawia, że żadne słowo, żadne pojęcie, żadna główna wypowiedź nie wyraża” (P, s. 17), można dostrzec pragnienie pomyślenia signifiant bez signifié? 
współbudujące go słowa, zdania, obrazy; gdy usiłujemy przedrzeć się do ukrytej w nim tajemnicy. I gdy zapisujemy owo szczególne spotkanie z głosem, wyobraźnią, światoodczuciem poety" ${ }^{\prime 17}$. Czy w czasach ekspansywnej (trwającej zresztą po dzień dzisiejszy) emancypacji rozmaitych dyskursów teoretycznych, z nieskrywaną przyjemnością snujących refleksję na swój własny temat, trzymanie się „blisko tekstu” nie oznacza po prostu praktyki interpretowania? Pod koniec lat siedemdziesiątych Janusz Sławiński opisywał najbardziej dotkliwe skutki owej emancypacji: „[...] narzędzia i procedury są dziś w mniejszym stopniu interesujące ze względu na ich ewentualną użyteczność badawczą, bardziej zaś jako obiekt możliwych eksplikacji, komentarzy i dopowiedzeń. Nie to, że są zdolne coś opisywać lub wyjaśniać, budzi głównie ciekawość, lecz to, w jakiej mierze same mogą być dalej objaśniane”18.

W świetle diagnozy Sławińskiego, a także wedle kryteriów rozumienia „bliskości”, jakie oferuje Stala, teoria od jakiegoś czasu zajmuje wobec literatury miejsce TAK ODLEGŁE, jak to tylko możliwe. W związku z czym postulat metodologiczny, jakim jest niewątpliwie potrzeba uprawiania lektury „blisko” tekstu, pełni w istocie dwuznaczną funkcję nakazująco-zakazującą. „Bliskość" może być bowiem wypowiedziana wyłącznie poza sobą, poza znaczeniem tego, o czym mówi, a nawet wbrew temu, co stara się otwarcie głosić. Postulat lekturowej „bliskości” może być jedynie wycofującą się z czytania zapowiedzią nadchodzącej lektury, wypowiadaną z pewnej stale rosnącej (z każdą kolejną, przybywającą literą) odległości, ale też odwlekłości ${ }^{19}$. Szaj zwróćmy na to uwagę - postuluje „bliskość” lekturową, odraczając samą lekturę. Uprawia jej "czystą" postać, możliwą wszak do zrealizowania jedynie w metadyskursie. Jak zatem zainicjować „bliskość” czytania, skoro każda jej definicja, nawet ta najprostsza, podlegając nieuchronnemu prawu zwłoki, staje się definicją negatywną? Sławiński pisał o sytuacji, w której teoria, uczyniwszy samą siebie przedmiotem własnych dociekań, przejęła de facto funkcję literatury, w związku z czym ona także stała się specyficznym jej rodzajem. $Z$ tego punktu widzenia zajęła wobec niej (choć już inaczej rozumianej) miejsce TAK BLISKIE, jak to tylko możliwe. Nie pisząc o literaturze wcale, pozostaję jej najbardziej wierny. Praxis „bliskości” ma sens jedynie w tych okolicznościach, na gruncie ściśle przylegającego samoodniesienia, gdy teoria jedynie „mówi, że gdy mówi, to mówi” ${ }^{20}$. Lecz nawet w tej wydawałoby się, że doskonałej formie relacji, „bliska" (auto)lektura będzie lekturą wciąż-nie-dość-blisko, więcej: wciąż na pewną odległość, na

\footnotetext{
${ }^{17}$ M. Stala, Blisko wiersza. 30 interpretacji, Kraków 2013, s. 5.

${ }^{18} \mathrm{~J}$. Sławiński, Zwłoki metodologiczne, [w:] tegoż, Teksty i teksty, Warszawa 1991, s. 39.W innym jeszcze miejscu Sławiński odnotowuje: „Proces ewolucyjny dzisiejszej humanistyki przypomina [...] serię epidemii - szybko się rozprzestrzeniających, ale stosunkowo krótkotrwałych. Jeszcze jedna nie wygasła, a już popędza ją druga [...] Szybka rotacja nie wyeksploatowanych języków nie pozwala żadnemu z nich bezwzględnie zapanować nad daną dyscypliną. W rezultacie nie ma szans, by ustalił się w niej jakiś miarodajny paradygmat, umożliwiający porządkowanie narastających doświadczeń metodologicznych" (tamże, s. 40).

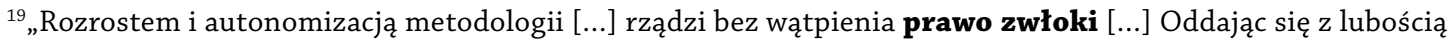
roztrząsaniu metod, odsuwamy w nieokreśloną przyszłość moment, w którym należałoby się nimi posłużyć" (J. Sławiński, dz. cyt., s. 41, wyr. za źródłem).

${ }^{20}$ Michel Foucault pisał niegdyś: „W chwili, gdy mówię po prostu «mówię» [...] [j]estem bezpieczny w niezdobytej fortecy, gdzie twierdzenie się potwierdza, dostosowując się ściśle do siebie samego, nie wychodząc na margines, zażegnując wszelkie niebezpieczeństwo błędu, skoro nie mówię niczego innego, jak tylko to, że mówię. Zdanieprzedmiot i zdanie, które tamto wypowiada, łączą się ze sobą bez przeszkód i bez niedomówień nie tylko od strony mowy, o którą chodzi, lecz także od strony podmiotu, który mowę tę artykułuje. Prawdą jest więc, niekwestionowaną prawdą, że mówię, gdy mówię, że mówię" (M. Foucault, Myśl zewnętrza, przeł. B. Banasiak, [w:] tegoż, Powiedziane, napisane. Szaleństwo i literatura, wybór i oprac. T. Komendant, tłumacze różni, posł. M.P. Markowski, Warszawa 1999, s. 173-174).
} 
przykład - na odległość śladu, którego produkcją od zawsze się trudni ${ }^{21}$. Lektura "prawdziwie” bliska oznacza bowiem kres komentarza. W tym sensie postulat mówiący o „posuwaniu rozumienia możliwie jak najdalej” (ŚŚ, s. 84), co w tym szczególnym przypadku oznacza - paradoksalnie - „jak najbliżej” (litery tekstu, signifiant), będzie postulatem metafizycznym. W tym sensie również „dotkliwość" będzie przypadkiem granicznym (Derrida powiedziałby być może, że negacją ${ }^{22}$ ) „bliskości”. Nie przynależąc wszak do jej dziedziny, próbuje opisać ją z drugiej strony. Lektura „bliska” - powtórzmy - może co najwyżej dążyć do „dotkliwości”, nigdy wszak jej nie osiągając, nawet jeśli ta oznacza także świadomość niemożliwości zamknięcia relacji „bliskości”: „Słowo to wskazywałoby [...] na dotkliwą niemożność scałościowania wyników interpretacji, dotkliwą wieloznaczeniowość tekstu, która nie poddaje się zabiegom hermeneutycznym" (ŚŚ, s. 90). Szaj identyfikuje „dotkliwość” z przywoływaną przezeń wcześniej formułą Gadamera opisującą "doświadczenie tekstu literackiego jako "porażenie przez sens tego, co powiedziane», które nie prowadzi do harmonijnego skupienia sensu, ale przekracza jakikolwiek horyzont oczekiwań” (ŚŚ, s. 90, wyr. G.P). „W niemieckim oryginale - pisze dalej - «porażenie» to zostało określone jako Betroffenheit, w którym to słowie słychać także czasownik treffen - trafiać, i jego stronę bierną: betroffen werden - być trafionym, ugodzonym, uderzonym" (ŚŚ, s. 90, wyr. G.P.). Kojarzy także „dotkliwość” z „pchnięciem” (Stoß) Heideggera. I wreszcie z Derridy doświadczeniem lektury jako „dotkliwej próby”, której dotkliwość bierze się stąd, że każdy poemat jest zarówno raniący, jak i będący raną (ŚŚ, s. 90). Wszystkie te liczne, metaforyczne asocjacje łączy intencjonalna redukcja oddzielenia, będącego budulcem „bliskości”.

\section{"Bliskość” śladu}

Nie istnieje - z punktu widzenia dekonstrukcji - takie znaczenie tekstu, które wykraczałoby „poza” jego granice. Na tym przekonaniu ufundowany został, zrekonstruowany przez Szaja spór pomiędzy dekonstrukcją a hermeneutyką nowoczesną, która - dla odmiany - istnienie transcendentalnego signifié zakłada. $Z$ racji tego, że hermeneutykę nowoczesną interesuje nie sam tekst, lecz jego sens, którego tekst może być jedynie przekaźnikiem, słuszne wydaje się, by nadać jej miano lektury zewnętrznej (wobec tekstu). „Zewnętrzność” (inaczej: zapośredniczenie, niedostępność) sensu nie pochodzi od tekstu, np. jako rezultat jego niewyczerpanej znaczeniorodności. Jest raczej odwrotnie: to sens $\mathbf{z}(\mathbf{d}) \mathbf{r a d z a}$ tekst, który, jak tylko się pojawia, ustanawia jego wtórną, a przez to niedoskonałą postać. Konsekwencją przyjęcia tej - jak się wydaje - dalekosiężnej perspektywy jest obniżona wrażliwość czytelnika na to, co zaledwie pośredniczy w dostępie do sensu, czyli na tekstualny (znakowy) aspekt dzieła (nie ukrywajmy wszak, że jednym z horyzontów tej myśli zawsze będzie wiara w przezroczystość języka). Istotne wobec tego jest to, co słabo lub zgoła w ogóle niewidoczne (ukryte, przesłonięte), co dopiero należy uobecnić (w procesie rozumienia). Niewidoczne, jako że - właśnie - zapośredniczone musi więc oznaczać (bardziej) odległe. Obciąża zatem lekturę hermeneutyczną odczuwalna nieobecność znaczącego.

\footnotetext{
${ }^{21}$ Za Pawłem Dyblem powtórzy Szaj: „każde znaczące jest sobą jedynie o tyle, o ile jest już poza sobą” (ŚŚ, s. 87; P. Dybel, Oblicza hermeneutyki, Kraków 2012, s. 42). Czy to nie jedna z formuł transcendencji?

${ }^{22}$ Zob. J. Derrida, Ousia i gramme. Przypis do przypisu z „Sein Und Zeit”, przeł. A. Dziadek, przekł. poprawił

J. Margański, [w:] tegoż, Marginesy filozofii, przeł. A. Dziadek, J. Margański, P. Pieniążek, Warszawa 2002,

s. 57-100 (tu zwłaszcza: Parafraza: punkt, linia, płaszczyzna).
} 
Z dekonstrukcją jest - jak już zostało to ustalone - na odwrót. Ta bowiem, rozumiejąc sens jako efekt gry tekstowej (tekst z(d)radza sens), uprawia lekturę wewnętrzną, skupiając swoją uwagę - per analogiam - na tym, co na wskroś widoczne, co (jednak) w tradycji zachodniej metafizyki uznawane było jedynie za przedstawienie. A skoro widoczne (widzialne), to pewnie i bliższee, (mniej) odległe. Kto jednak chce uznać lekturę dekonstrukcyjną za lekturę - par excellence - pozostającą blisko tekstu, musi uczynić z materii tekstu stabilny (w sensie odległościowym, relacyjnym) punkt odniesienia do określenia relacji bliskości. Bliskość prawdziwa (nie pozorna) nie może pod żadnym względem okazać się relacją relatywną, względną, tj. nie może być określana względem czegoś, co albo - z punktu widzenia dekonstrukcji - w ogóle nie istnieje (zewnętrzny sens), albo - z punktu widzenia hermeneutyki - jest pozycyjnie nieokreślone (wciąż zapośredniczone). Bliskość może się wyistoczyć jedynie wobec tego, co JEST. I to w sposób ustalony raz na zawsze, np. wobec pisma, które - jak komentuje Derrida - w tradycji zachodniej stanowi jedynie unaocznienie czy uzewnętrznienie języka ${ }^{23}$. Ale - powie także francuski filozof - „zdekonstruowanie tej tradycji nie polega na jej odwróceniu, na uniewinnieniu pisma"24, co w tych okolicznościach oznaczałoby nie tylko redukcję pisma do postaci signifiant, lecz także uczynienie z niej wewnętrznej (uprzywilejowanej) strony języka. „Dlatego właśnie autor O gramatologii tak bardzo naciskał na prymat pisma nad mową” ${ }^{25}$. „Podczas gdy dla Gadamera to, co istotne, rozgrywa się na poziomie znaczonego, to Derridiańska redukcja do znaczącego istotnie komplikuje sprawy..."26.

Ontologia tekstu jako śladu nie spełnia tych warunków: „[...] właśnie ta logika [logika différance - dop. G.P.] decyduje o «śladowości» tekstu i jego «zanieczyszczonym» charakterze. Jeśli bowiem każdy znak nosi w sobie jakby «wspomnienie» poprzedzających go znaków, a jednocześnie niejako «zapowiada» znaki, które przyjdą po nim, to następuje załamanie jego stabilnej tożsamości (ŚŚ, s. 86, wyr. G.P.). Ślad, krusząc opozycję obecne/nieobecne (tekst/sens), nie daje się utożsamić ani z obecnością czegoś, ani też z tego czegoś nieobecnością. Słowem: chcąc mówić o śladzie, winniśmy odmówić mu tego czegoś (istotowości, przedmiotowości?), z czym można by ów ślad powiązać. Nie chodzi też o to, że ślad - nie mogąc być bliskim - jest, niejako w zamian, odległy. Ślad nie jest (telos), lecz odsyła. Podobnie jak rozsunięcie, jak rozplenienie, wreszcie jak różnia, ma w sobie motyw genetyczny, produkujący dystans (różnice). To właśnie ślad sprawia, że „bliska” lektura (podobnie zresztą jak transcendentna) jest tyleż konieczna,

\footnotetext{
${ }^{23}$ Zob. J. Derrida, Zewnętrze i wnętrze, [w:] tegoż, O gramatologii, przedmowa, posłowie i przekład B. Banasiak, Łódź 2011, s. 58-74.

${ }^{24}$ Tamże, s. 67.

${ }^{25}$ P. Szaj, Czy można pogodzić..., dz. cyt., s. 72. Wyr. G.P. Oczywiście autor może w tym miejscu, niejako w geście obronnym, usprawiedliwić się, że sens pisma w rozumieniu dekonstrukcyjnym zdecydowanie nie mieści się w porządku ustalonym przez tradycję metafizyczną (fonocentryczna opozycja: mowa/pismo), w związku z czym sprowadzanie pisma do wymiaru signifiant jest nieuprawnione. Skoro jednak dekonstrukcyjne rozumienie pisma wykracza poza tradycyjny porządek, to w jakim sensie może ono stanowić różnicę (opozycję) w stosunku do podtrzymującego tę tradycję stanowiska Gadamera, który „pismo nieodmiennie traktował jako wyobcowaną mowę”? (s. 72). Tym bardziej, że wcześniej Szaj pisze: „Etymologie [rozumienia i samorozumienia - dop. G.P.] dowodzą, zdaniem Gadamera, że w podstawowych pojęciach hermeneutycznych tkwi już głęboko wydobywany przez Derridę motyw différance, że - jednym słowem - każdy hermeneuta zgodziłby się z Derridiańską tezą o ontologicznym pierwszeństwie różnicy przed tożsamością: [...] «różnica tkwi w tożsamości, w przeciwnym razie tożsamość nie byłaby tożsamością» [...] Derridzie [...] nie chodzi wcale (albo: nie tylko chodzi) o różnicę tkwiącą w tożsamości, ale - jak dobrze wiemy - o sam mechanizm różnicowania" (tamże, s. 72).

${ }^{26}$ Tamże. Wyr. - G.P.
} 
co niemożliwa. Ślad może być też rozumiany inaczej. Jak bliskość jest bliskością wobec czegoś (np. wobec tekstu), tak ślad może się okazać śladem tego czegoś.

Jak [...] rozumieć postulat „trzymania się blisko tekstu” w hermeneutyce ponowoczesnej? Byłoby to swoiste „śledzenie śladów”, albo też - jak pisze Andrzej Zawadzki - „naśladowanie, kroczenie po śladach, tropienie ich i odczytywanie, odpowiadanie na nie własnym śladem". Słowem: kroczenie po śladach tekstu i podążanie w ślad za ich znaczeniorodną grą... ${ }^{27}$ (ŚŚ, s. 88-89, wyr. - G.P.).

W nieprzypadkowym wyrażeniu „ślad tekstu” (,ślady tekstu”) sam ślad staje się niewątpliwie czymś poślednim. Zostaje, można by rzec, ubezwłasnowolniony. „Ślad tekstu” - wbrew pozorom - nie jest tym samym, co podlegająca logice différance „śladowość tekstu”, jak tym samym nie może być w żadnym razie, gdy mówimy już o lekturze, „kroczenie po śladach” i „kroczenie po śladach tekstu”. W połączeniu wyrazowym „ślad tekstu”, gdzie słowo „tekst” musi wystąpić przed polskim czytelnikiem w formie dopełniaczowej (i nie ma na to żadnej rady), ów tekst staje się czymś nieuchronnie przeszłym, czymś absolutnie byłym. Choć jakiś ślad tekstu (jeszcze) jest, to samego tekstu (już) nie ma. Jakby tekst był całością, a ślad zaledwie tej całości fragmentem. Ślad odsyła nie do kolejnych śladów, by uświadomić czytelnikowi wymóg ciągłego rozpoczynania od nowa, pozostawania wciąż na początku lekturowej drogi ${ }^{28}$, lecz do własnej przeszłości, do tekstu, który niegdyś był czymś więcej niż to, co teraz stanowi tylko jego ślad. Definicję lektury nie-transcendentnej, polegającą na nie-porzucaniu „zainteresowania dla znaczącego, formy, języka, materii, z jakiej ustrukturyzowany został tekst" (ŚŚ, s. 83), buduje Szaj, odwracając jedną z wypowiedzi Derridy na temat tego, co znaczy „transcendować”. „ «Transcendować» to w tym wypadku porzucać zainteresowanie znaczącym, formą, językiem (proszę zauważyć, że nie mówię «tekstem») na rzecz znaczenia lub przedmiotu odniesienia...”29. Czy wystarczy utworzyć formę zaprzeczoną czasownika „porzucać”, tj. zainteresować się znaczącym, by lektura transcendentna stała się lekturą nie-transcendentną? Tekst, o którym - proszę zauważyć - Derrida jedynie mówi, że o nim nie mówi, wyraźnie transcenduje porządek, o którym z kolei mówi we wskazanym ustępie tak, jakby ten wydawał się na wskroś oczywisty i jednoznaczny, mianowicie porządek znaczącego, porządek formy i języka ${ }^{30}$. Nie w tym rzecz, że tekst to prawdopodobnie coś więcej (i coś innego) niż (tylko) signifiant. Być może ślad materialnie przekracza ów porządek, a wtedy zajmowałby on symetryczną w stosunku do sensu pozycję względem tekstu, przy założeniu, że o ile nie sposób

\footnotetext{
${ }^{27}$ Cyt. wewn.: A. Zawadzki, Literatura a myśl słaba, Kraków 2009, s. 157.

${ }^{28}$ Zob. P. Szaj, Czy można pogodzić..., dz. cyt., s. 74.

${ }^{29} \mathrm{~J}$. Derrida, Ta dziwna instytucja..., dz. cyt., s. 190.

${ }^{30}$ Tekst transcenduje porządek znaczącego z innego jeszcze powodu. „Tekst bowiem, jako splot (od łac. texere) tekstualnych fałd, warstw, zagięć, warunkuje czytanie jako ich de-konstruowanie, tzn. od-wijanie. Zdaniem Derridy jednak praca ta pozostać musi nieskończona, gdyż fałda czy też zmarszczka - le pli - jest tym «elementarnym» elementem tekstu, który uniemożliwia jego semantyczne zamknięcie. Niemożliwa okazuje się więc pełna eks-pli-kacja znaczenia tekstu, w sensie: wygładzenie wszystkich jego fałd. Dla hermeneutyki jest to oczywiście źródło dramatu. Ale jest to także - po prostu - warunek możliwości uprawiania jakiejkolwiek hermeneutyki: gdyby wszystkie tekstualne fałdy dawały się bezproblemowo "odwinąć», hermeneutyka w ogóle nie byłaby potrzebna” (ŚŚ, s. 89). Czy o nieskończoności pracy interpretacji, o niemożności „pełnej eks-pli-kacji” znaczenia tekstu decyduje ilość fałd w tekście, tzn. nie sposób wygładzić wszystkich fałd tekstu, gdyż są one zwyczajnie - nieskończenie liczne? Czy jest to może raczej kwestia ich jakości? Skoro nie wszystkie fałdy dają się bezproblemowo „odwinąć”, to można jednocześnie założyć, że odnajdziemy wśród nich i takie, które w pełni ulegają temu procesowi. Po czym rozpoznać, która fałdka tekstu jest odwijalna, a która nie? Po czym rozpoznać gładkość tekstu, a tym samym - redukcję fałdki?
} 
sensu utożsamić z porządkiem znaczonego, o tyle śladu nie sposób utożsamić z porządkiem znaczącego. Byłby on wówczas tak samo zewnętrzny wobec tekstu, tyle że „z drugiej strony”. Funkcjonalnie ślad byłby odwrotnością sensu. Przez to, że on ciągle JEST (dany czytelnikowi w sposób naoczny), jako łańcuch signifiants właśnie, nie daje się w żaden sposób wytropić. Wytropić (wyśledzić), znaczy bowiem uobecnić. Mówiąc jednak o „śladach tekstu”, myślimy raczej o procesie odwrotnym, o - można rzec - jakichś jego pozostałościach w postaci śladowej, o czymś, co musi kojarzyć się ze szczególną formą uobecniania, jaką jest uobecnianie nieobecnego, czyli unieobecnianie dqzżace do nieobecności. Tropienie śladu nie wchodzi więc w grę. Ale „coś więcej” w relacji tekstu do śladu oznacza nie tylko stosunek ilościowy, który zachowywałby esencję, lecz również różnicę jakościową. Ślady tekstu stają się zarazem śladami po tekście. Dopiero po tych śladach biegnie nasza lektura. Wyjątkowość przyimka „po” polega tutaj na tym, że jego pozycja wynikająca z reguł syntagmatycznych (prepozycja) wchodzi w konflikt z pozycją, na którą wskazuje jego semantyka. Zgodnie z obraną tu linią interpretacyjną ślad „po”, współbudujący formułę „ślady po tekście”, uzmysławia tym samym paradoksalną pozycję śladów, które - chcąc nie chcąc - zjawiają się dwukrotnie: „przed” tekstem i „po” tekście. 


\title{
SEOWA KLUCZOWE:
}

transcendencja

\section{tekst}

\section{BLISKOść}

\begin{abstract}
AbStrakT:
Artykuł jest głosem polemicznym wobec tekstu Patryka Szaja zatytułowanego Śledzenie (śladów) sensu. Tekst i lektura w hermeneutyce ponowoczesnej, w którym autor pokazuje, że zaproponowana przez Szaja kategoria „bliskości”, określająca ontologię lektury uprawianej przez hermeneutykę ponowoczesną, jest metafizycznie obciążona. Obecne w interpretacji Szaja specyficzne rozumienie dekonstrukcji jako odwrotności hermeneutyki nowoczesnej powoduje, że „bliskość” nie tylko uprzywilejowuje wnętrze (kosztem zewnętrza), signifiant (kosztem signifié), ale też ze „śladu” czyni odwrotność „sensu”. Ich wypadkową, można rzec, jest dopiero tekst.
\end{abstract}




\section{W NĘTRZE}

p o

\section{S I G N I F IÉ S I G N I F I A N T}

NOTA O AUTORZE:

Grzegorz Pertek - doktorant na Wydziale Filologii Polskiej i Klasycznej Uniwersytetu im. Adama Mickiewicza w Poznaniu. Interesuje się polską poezją XX wieku, teorią literatury, filozofią transgresji. Publikował m.in. w „Czytaniu Literatury”, „Przestrzeniach Teorii”, „Poznańskich Studiach Polonistycznych”, ,Wielogłosie”, „Aluze”. 